\title{
АНАЛІЗ МОЖЛИВОСТЕЙ ЕЛЕКТРОННОЇ КАРТОГРАФІЧНОЇ НАВІГАЦІЙНОЇ ІНФОРМАЦІЙНОЇ СИСТЕМИ ДЛЯ ОПТИМАЛЬНОГО КЕРУВАННЯ РУХОМ СУДНА
}

В статті розглянуто властивості електронних картографічних навігащійних інформаційних систем для керування рухом судна на прикладі використання системи Transas-Navi-Sailor-4000. На основі автоматичного аналізу інформації про стан судна за допомогою електронних картографічних навігащійних інформаційних систем можливо здійснювати очінювання морської навігаційної обстановки, забезпечити безпеку судноводіння на основі визначення містоцеположення морських об'єктів та прокладки оптимального курсу судна.

В стаття також представлена загальна структурна схема електронної картографічної навігаційної інформачійної системи.

Електронні картографічні навігаційні інформаџійні системи $\epsilon$ виключно ефективним засобом навігачії, які істотно скорочують навантаження на вахтового помічника $i$ дозволяють приділяти максимум часу спостереження за навколишнім оточенням і виробленні обтрунтованих рішень з управління судном.

Ключові слова: електронна картографічна навігачійна інформачійна система, керування судном, безпека судноводіння

Вступ. Розвиток сучасної електроніки, зв'язку, обчислювальної техніки i програмних комплексів, а також систем відображення, стало стимулом для реалізації технології Е-навігації на основі створення нового підходу - геоінформаційних систем судноводіння, що забезпечує підвищення рівня безпеки судноплавства, захисту життя людей, вантажів, що перевозяться, охорони довкілля [1]. Інтеграція сучасних навігаційних пристроїв і приладів 3 комп'ютерними системами дозволило створити електронну картографічну навігаційну інформаційну систему (ECDIS - Electronic Chart Display and Information System) [2, 3]. Міжнародною морською організацією (MMO) на підставі розроблених правил і вимоги рекомендують використовувати ECDIS, яка сприяє виконанню заданих вимог з безпеки судноводіння [4].

Дана система дозволяє здійснювати відображення карт і місцезнаходження судна, вести прокладку траси руху, а також контроль відхилень від заданого маршруту. Крім цього, завдяки інтелектуальній базі даних морських об'єктів дозволяє проводити розрахунок безпечного курсу, здійснює попередження судноводія про небезпеку, а також проводити електронне ведення суднового журналу, контроль управління авторульовим та інші додаткові функції $[1,2]$.

Розроблена ECDIS $\epsilon$ виключно ефективним засобом управління водним транспортним засобом за допомогою навігаційних даних, а також про стан судна. Крім цього дана система істотно скорочує навантаження на вахтового помічника і дозволяє приділити максимум часу спостереження за навколишнім оточенням, а також виробити обгрунтоване рішення по управлінню судном відповідно курсу $[2,3]$. Однак маючи в своєму арсеналі потужний програмно-апаратний інструментарій (ECDIS) для контролю i управління судном при судноводінні у випадках відхилення судна або зміни обстановки (умов) відсутня загальні підходи для використання її на практиці. У зв'язку 
3 цим необхідно розглянути можливості даної системи і надати загальний алгоритм управління судном незалежно від навігаційної обстановки і причин їх зміни.

Аналіз літератури. Аналітичний огляд літератури [2, 3, 5] показав, що можливості використання ECDIS має інформаційний характер і надає судноводій на його запит характеристики i параметри морських об'єктів на електронній картографічній основі району плавання судна, а також дані про метеорологічних умовах і умовах плавання по всьому маршруту слідування судна. Розглянемо систему ECDIS на прикладі Navi-Sailor 4000 (див. Рис.1), яка розроблена TRANSAS MARINE INTERNATIONAL відповідно до останніх стандартами і резолюціями MMO [6]. Пропонована система $\epsilon$ навігаційної інформаційною системою, яка відображає інформацію 3 навігаційних датчиків і положення судна на електронній навігаційній карті щодо маршруту руху. Поєднання всієї інформації на одному екрані забезпечує можливість високого рівня сприйняття ситуації і вироблення рішення на управління судном. Система допомагає планувати маршрут руху і здійснювати моніторинг його по ходу проходження.

Мета статті. Тому метою даної статті є провести аналіз і представити результати можливостей щодо використання ECDIS для керування судном для підвищення ефективності судноводіння під час його експлуатації в складних умовах для забезпечення безпеки управління судна.

Виклад основного матеріалу. Програмно-апаратний комплекс Navi-Sailor 4000 являє собою навігаційну інформаційну систему 5 покоління, призначену для відображення інформації з навігаційних датчиків і суднових радарів на електронній навігаційній карті. Структурна схема можливих варіантів підключень та використань навігаційних пристроїв і приладів представлено на рис.1. У таблиці 1 представлені результати опису робочих станцій до застосування.

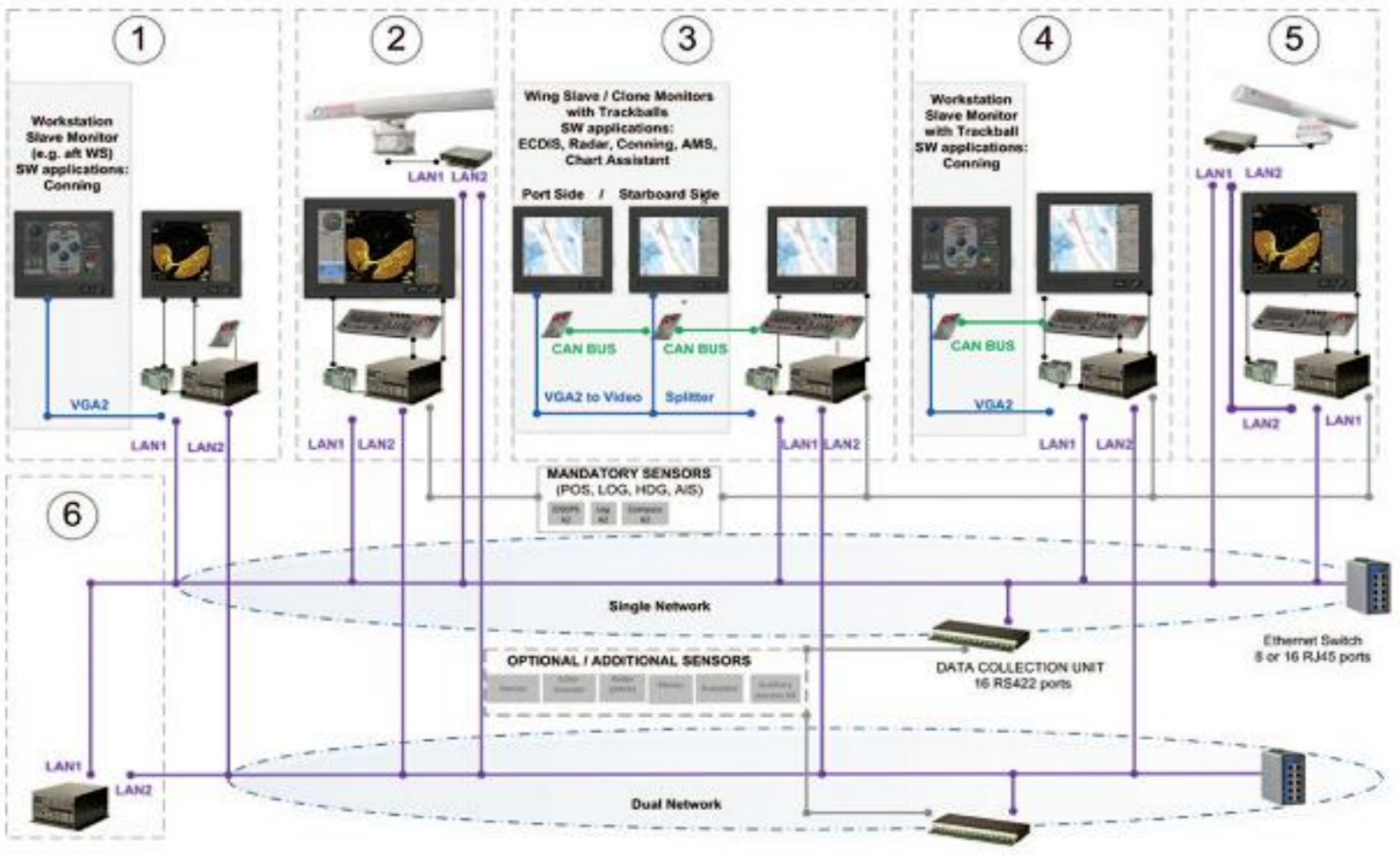

Рисунок 1 - Структурна схема ECDIS Navi-Sailor 4000

Характеризуючи ECDIS Navi-Sailor 4000 можна відзначити наступне, що навігаційний характер системи визначається як традиційними завданнями ECDIS 14 
(попередня і виконавча прокладка, корекція поточного місця), так і новими завданнями по оцінці навігаційної безпеки плавання, можливості коригування електронних карт, організації подачі завчасної сигналізації і т.п. Крім того, ECDIS Navi-Sailor 4000 відображає на екрані дисплея точні картографічні дані морської карти в реальному масштабі часу, тобто в поєднанні з поточним місцезнаходженням судна, отриманим від суднових навігаційних приладів (DGPS, GPS). В даному випадку ECDIS Navi-Sailor 4000 обробляє і представляє інформацію і від інших навігаційних датчиків, наприклад гірокомпас, лага, ехолота, РЛС, ЗАРП.

Система Navi-Sailor 4000 призначена для вирішення наступних [5, 6, 7]:

I. Навігаційніх завдання:

складання попередньої електронної прокладки майбутнього рейсу з проведенням розрахунків швидкості, відстаней, часу плавання;

висновок навігаційних даних від пріемоіндікаторов розташування судна на електронну карту;

відображення параметрів руху судна за маршрутом;

можливість спостереження за зміною місця розташування захоплених нерухомих об'єктів щодо руху власного судна;

відображення на електронній карті цілей, захоплених на РЛС (ЗАРП).

II. Інформаційно-навігаційних завдань:

ведення електронного суднового журналу та виведення його даних на друк;

відновлення відображення траєкторії шляху судна і записів суднового журналу будьякого рейсу з можливістю запису місця розташування судна;

сигналізація про наближення до шляхової поворотної точки, відхилення від встановлених параметрів руху судна і несправності самої системи;

вимір географічних координат, дистанцій і пеленгів будь-яких (морських) об'єктів карти, а також автоматична, напівавтоматична і ручна коректура електронних карт;

відображення карти в зручному масштабі (масштабування) на екран і врізка електронної карти в різних форматах, в тому числі стандарті ECDIS;

отримання додаткової довідкової інформації про картографічні об'єктах, засобах навігаційного обладнання, а також гідрографічних та інших відомостей з бази даних електронної карти;

запис (архівація) траєкторій цілей на диск і можливість їх відображення разом 3 відповідною траєкторією власного судна і записами суднового журналу.

На рис. 2. представлена структурно-логічна схема інформаційних зв'язків та взаємодії елементів електронної картографічної навігаційної інформаційної системи Navi-Sailor 4000. В даному випадку ECDIS Navi-Sailor 4000 можливо поділити на: програмну середу ECDIS з вбудованим інструментарієм обробки навігаційної інформації; електроні карти, які завантажуються; інтерфейс з якого надходять данні 3 суднових навігаційних пристроїв; засоби відображення та збереження даних; блок обчислювання даних; інтерфейс підключення до автоматичної ідентифікаційної системи з базами даних, а також окремий інтерфейси взаємодії РЛС (ЗАПР) та авторульовим.

Застосування ECDIS Navi-Sailor 4000 можливо проводити в інтерактивному або повністю автоматизованому режимі. Для його застосування існують рід сценаріїв для планування та розрахунку маршрутів руху судна 3 необхідною обробки даних що поступають з навігаційних пристроїв та суднового РЛС за допомогою використанням інструментарію (дивись рис.2).

Особливістю використання навігаційних функцій починається після закладки необхідного маршруту руху судна. Маршрут можливо побудувати автоматично або в ручному режимі. Також необхідно встановити для більш якісного контролю реперні точки, в яких можливо надати додаткову дані. Навігаційні функції пов'язані 3 судновими пристроями. За допомогою інструментарію навігаційних функцій можливо 
визначити місцеположення судно, здійснити контроль по заданому маршруту руху судна, пеленг та дистанції до інших морських об'єктів, корегування навігаційних даних. При цьому можливо розробити додаткову програму, яка в залежності (або за наявністю) додаткових даних буде проводити корегуючи розрахунок місцезнаходження судна під час судноводіння при відсутності навігаційних даних. Також існує модуль для підключення автоматична ідентифікаційна система з бібліотеками та модуль даних з суднових РЛС (ЗАПР), які наносяться на електрону карту при необхідності.

Таблиця 1 - Опис варіантів робочих станцій

\begin{tabular}{|c|c|c|c|}
\hline $\begin{array}{l}\text { Варіант } \\
\text { підклю- } \\
\text { чення }\end{array}$ & $\begin{array}{l}\text { Головна } \\
\text { відмінна }\end{array}$ & $\begin{array}{l}\text { Назва } \\
\text { робочій } \\
\text { станції }\end{array}$ & $\begin{array}{c}\text { Додаткові цілі за рахунок використання } \\
\text { додаткового обладнання. }\end{array}$ \\
\hline 1 & $\begin{array}{l}\text { Додаткова } \\
\text { робоча станція }\end{array}$ & Робоче місце & $\begin{array}{l}\text { - ECDIS і РЛС відома або резервна робоча } \\
\text { станція; } \\
\text { - Робоча станція для планування маршруту; } \\
\text { - Робоча станція для обробки графіків; } \\
\text { - Дисплей управління; } \\
\text { - Кормова робоча станція. }\end{array}$ \\
\hline 2 & $\begin{array}{l}\text { Використання } \\
\text { радара } \quad \text { S- } \\
\text { діапазону }\end{array}$ & $\begin{array}{l}\text { Радар } \quad \mathrm{S}- \\
\text { діапазону }\end{array}$ & $\begin{array}{l}\text { - Додаткова робоча станція для резервного } \\
\text { копіювання ECDIS; } \\
\text { - Робоча станція моніторингу ситуацій; } \\
\text { - Дисплей управління; } \\
\text { - Робоча станція для обробки графіків. }\end{array}$ \\
\hline 3 & $\begin{array}{l}\text { Резервне } \\
\text { копіювання } \\
\text { ECDIS }\end{array}$ & $\begin{array}{l}\text { Тип } \\
\text { затверджено } \\
\text { го } \\
\text { резервного } \\
\text { копіювання } \\
\text { ECDIS }\end{array}$ & $\begin{array}{l}\text { - Додаткова робоча станція резервного } \\
\text { копіювання радара; } \\
\text { - Робоча станція для планування маршруту; } \\
\text { - Робоча станція для обробки графіків; } \\
\text { - Дисплей управління; } \\
\text { - Робоча станція моніторингу ситуацій; } \\
\text { - Монітори для аварійно-рятувальної станції. }\end{array}$ \\
\hline 4 & $\begin{array}{l}\text { ECDIS } \\
\text { затвердженого } \\
\text { типу } \\
\end{array}$ & $\begin{array}{l}\text { ECDIS } \\
\text { управління }\end{array}$ & $\begin{array}{l}\text { - Дисплей управління; } \\
\text { - Система моніторингу ситуацій. }\end{array}$ \\
\hline 5 & $\begin{array}{l}\text { Використання } \\
\text { радара } \quad \mathrm{X}- \\
\text { діапазону }\end{array}$ & $\begin{array}{l}\text { Радар } \mathrm{X}- \\
\text { діапазону }\end{array}$ & $\begin{array}{l}\text { - Додаткова робоча станція для резервного } \\
\text { копіювання ECDIS; } \\
\text { - Робоча станція моніторингу ситуацій; } \\
\text { - Дисплей управління; } \\
\text { - Робоча станція для обробки графіків. }\end{array}$ \\
\hline 6 & $\begin{array}{l}\text { Багатофункціо } \\
\text { нальна робоча } \\
\text { станція }\end{array}$ & $\begin{array}{l}\text { Робоча } \\
\text { станція }\end{array}$ & $\begin{array}{l}\text { - Робоче місце капітана; } \\
\text { - Робоча станція з кількома комутаторами; } \\
\text { - Робоча станція для запису даних. }\end{array}$ \\
\hline
\end{tabular}

Для підвищення якості керування судном існують додатковий модуль метеорологічних умов (прогноз погоди), за допомогою якого можливо визначити кризисні зону руху судна та остойчивість судна в реальному масштабі часу (або прогнозуючі дані).

Робота 3 картами також має деякі особливості. Так електронні карти будь то векторні або растрові карти повинні бути сертифіковані та відповідати встановленим вимогам ММО [4, 6]. До недоліків даної системи можна віднести часткове спільне використання в ECDIS растрових і векторних карт. При цьому, головна відмінність векторного зображення від растрового в наявності своєї власної бази даних з описом (в 
тому числі з координатами географічних і морських об'єктів). Крім цього необхідно дублювати проходження судна на паперовому носіях.

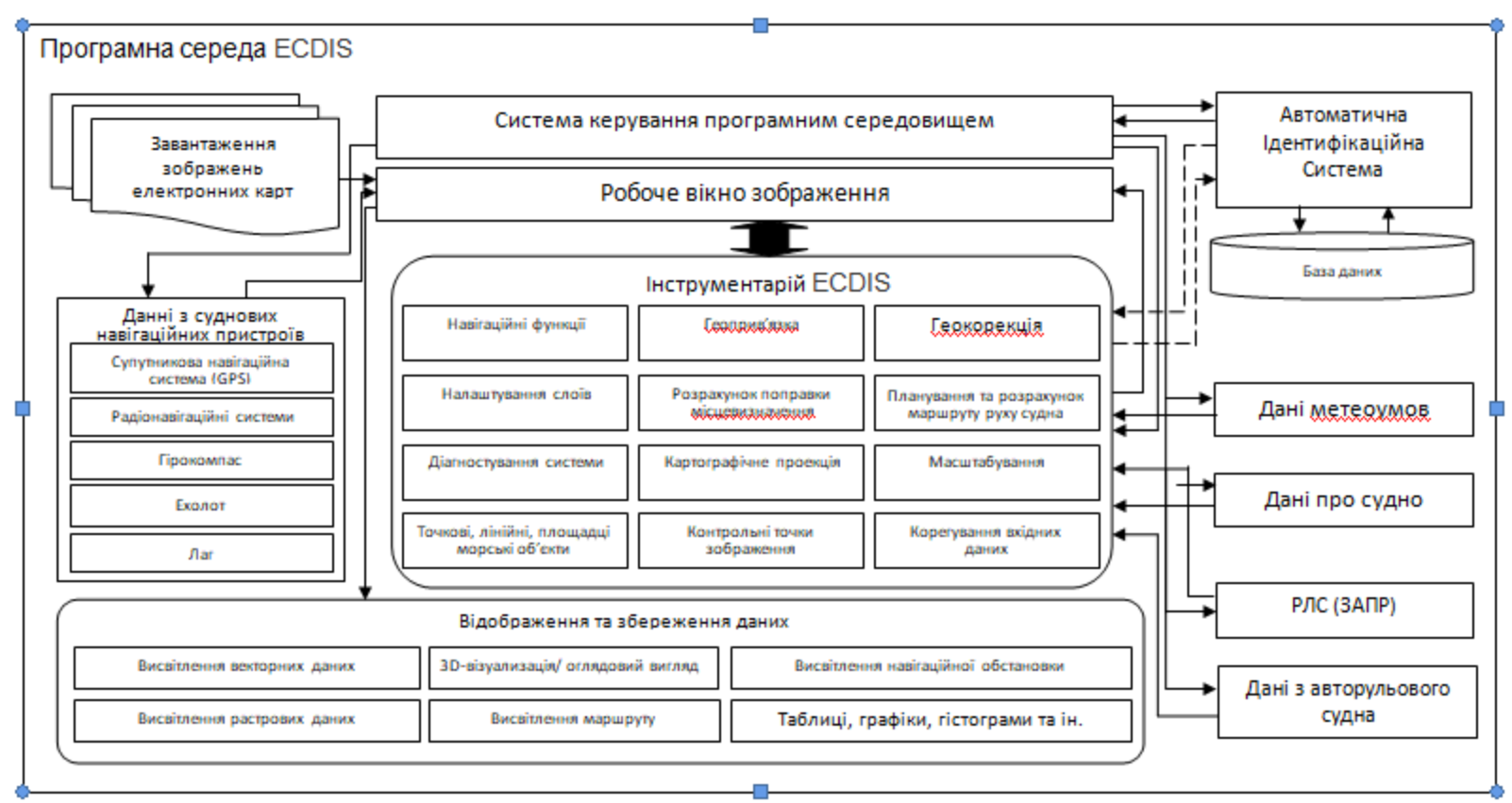

Рисунок 2 - Структурно-логічна схема інформаційних зв'язків та взаємодії елементів електронної картографічної навігаційної інформаційної системи

Висновки. Електронні картографічні навігаційні інформаційні системи $\epsilon$ виключно ефективним засобом навігації, які істотно скорочують навантаження на вахтового помічника i дозволяють приділяти максимум часу спостереження за навколишнім оточенням і виробленні обгрунтованих рішень з управління судном.

\section{ЛIТЕРАТУРА}

1. Вагущенко Л.Л. Системы автоматического управления движением судна // Л.Л. Вагущенко, Н.Н. Цымбал. - Одесса: Фенікс, 2007. - 328 с.

2. Вагущенко Л.Л. Современные информационные технологии в судовождении / Л.Л. Вагущенко - Одесса: ОНМА, 2013. - 135 с.

3. Пятаков Э.Н. Электронная навигация и картография / Э.Н. Пятаков. - Херсон: Гринь Д.С., 2017. - 336 с.

4. https://www.imo.org/en/OurWork/Safety/Pages/ElectronicCharts.aspx

5. Бурханов М.В. Навигация с ЭКНИС / М.В. Бурханов, И.М. Малкин. - М.: Моркнига, 2014. - 316 с.

6. https://cdn.wartsila.com/docs/default-source/marine-documents/presentations-technicalseminar-japan/presentations-in-english/the-future-of-safe-navigation-in-the-smartmarine-ecosystem.pdf?sfvrsn=e1011444_8

7. Демиденко, П.П. Судовые радиолокационные и радионавигационные системы: Учебное пособие - 2-е изд. перераб и доп. - Одесса: Фенікс, 2016 -368 с.

Тимощук А.Н., Елеазаров А.П., Гладкий А.Р.

\section{АНАЛИЗ ВОЗМОЖНОСТЕЙ ЭЛЕКТРОННОЙ КАРТОГРАФИЧЕСКОЙ НАВИГАЦИОННОЙ ИНФОРМАЦИОННОЙ СИСТЕМЫ ДЛЯ ОПТИМАЛЬНОГО УПРАВЛЕНИЯ ДВИЖЕНИЕМ СУДНА}

В статье рассмотрены свойства электронных картографических навигационных информачионных систем для управления движением судна на примере использования системы Transas-Navi-Sailor-4000. На основе автоматического анализа информации о 
состоянии судна при помощчи электронных картографических навигачионных информационных систем возможно осуществлять оценивание морской навигационной обстановки, обеспечить безопасность судовождения на основе определения местоположения морских объектов и прокладки оптимального курса судна.

Электронные картографические навигаџионные информационные системы является исключительно эффективным средством навигащии, которые существенно сокращают нагрузку на вахтенного помощника и позволяют уделять максимум времени наблюдения за окружающей обстановкой и выработке обоснованных ремений по управлению судном.

В статья также представлена обобщенная структурная схема электронной картографической навигационной информационной системы с логическими связями.

Ключові слова: електронна картографічна навігачійна інформаційна система, керування судном, безпека судноводіння

\section{Timoshchuk O.M, Eleazarov O.P, Gladkiy A.R}

\section{ANALYSIS OF CAPABILITIES OF THE ELECTRONIC CARTOGRAPHIC NAVIGATION INFORMATION SYSTEM FOR OPTIMAL VESSEL CONTROL}

The article considers the properties of electronic cartographic navigation information systems for vessel traffic control on the example of using the Transas-Navi-Sailor-4000 system. Based on the automatic analysis of information about the condition of the vessel with the help of electronic cartographic navigation information systems it is possible to assess the maritime navigation situation, ensure the safety of navigation based on the location of marine objects and laying the optimal course of the vessel.

Electronic cartographic navigation information systems are an extremely effective means of navigation, which significantly reduces the load on the shift assistant and allows you to spend maximum time observing the environment and making informed decisions about ship management.

The article also presents a general block diagram of an electronic cartographic navigation information system with logical connections.

Keywords: electronic cartographic navigation information system, ship management, navigation safety. 